\title{
Efisiensi Energi dan Reduksi Harga Total Produksi Hidrogen pada Siklus Sulfur-Iodine Seksi III Skala Pilot Menggunakan Analisis Pinch
}

\author{
Sonya Hakim Raharjo ${ }^{1}$, Ima Winaningsih ${ }^{1}$, Widayat Widayat ${ }^{2^{*}}$ \\ ${ }^{1}$ MagisterTeknik Kimia Fakultas Teknik, Universitas Diponegoro, \\ ${ }^{2}$ Departemen Teknik Kimia Fakultas Teknik, Universitas Diponegoro \\ Jl. Prof. Soedarto, SH, Kampus UNDIP Tembalang, Semarang, Indonesia 50275
}

\begin{abstract}
Abstrak
Proses produksi hidrogen melibatkan perpindahan panas dari satu aliran proses ke aliran proses yang lain atau dari aliran utilitas ke aliran proses dan sebaliknya. Hal ini memotivasi untuk dilakukan proses efisiensi energi. Pada siklus sulfur-iodine seksi III, proses dekomposisi HI merupakan bagian penting karena merupakan proses terakhir untuk menghasilkan $\mathrm{H}_{2}$. Beberapa unit peralatan dan unit utilitas yang ada dalam sistem proses ini membutuhkan dan menghasilkan energi yang cukup besar. Ditemukan bahwa beberapa penggunaan sistem energi ini dapat dioptimalkan melalui proses analisis efisiensi energi menggunakan analisis pinch. Peneltian ini menggunakan perangkat lunak HINT untuk melakukan analisa pinch dengan variasi minimum temperature approach (UTmin). Hasil analisa menunjukkan bahwa pada $\triangle$ Tmin $10 \mathrm{~K}$ diperoleh maximum energy recovery (MER) yang tinggi dan total harga produksi $\mathrm{H}_{2}$ yang paling rendah.
\end{abstract}

Kata kunci: maximum energy recovery; produksi hidrogen; efisiensi energy; harga total produksi; analisis pinch; minimum temperature approach (DTmin)

\begin{abstract}
[Title: Energy Efficiency and Total Price Reduction of Hydrogen Production in Sulfur-Iodine Cycle Section III Pilot Scale Using Pinch Analysis] The hydrogen production process involves the transfer of heat from one process flow to another or from the utility flow to the process flow and vice versa. This motivates to do energy efficiency. Sulfur-iodine cycle process is an important part because it is the last process to produce $\mathrm{H}_{2}$. Some equipment units and utility units that exist in the process system require and produce substantial energy. It is found that some usage of energy systems can be optimized through the process of energy efficiency analysis using pinch analysis. In this report, HINT software was used to conduct the pinch analysis with variations in the minimum temperature approach (DTmin). Analysis results showed that at $\triangle T$ min $10 \mathrm{~K}$, high maximum energy recovery (MER) and the lowest total $\mathrm{H}_{2}$ production cost could be obtained.
\end{abstract}

Keywords: maximum energy recovery; hydrogen production; energy efficiency; production total cost; pinch analysis; minimum temperature approach (Dtmin)

\section{Pendahuluan}

Hidrogen merupakan bahan bakar yang banyak mendapatkan perhatian untuk dikembangkan, karena merupakan bahan bakar yang ramah lingkungan dan

\footnotetext{
${ }^{*}$ Penulis Korespondensi.

E-mail: widayat@live.undip.ac.id
}

berpotensi menggantikan bahan bakar fosil. Reaksi pembakaran gas hidrogen tidak menghasilkan gas yang berbahaya pada lingkungan karena hanya menghasilkan uap air. Selain sebagai bahan bakar untuk transportasi, hidrogen dapat digunakan sebagai bahan baku untuk produksi pupuk, pengilangan minyak dan industri lainnya. Hidrogen merupakan unsur jarang sekali ditemukan dalam bentuk bebas. 


\section{TEKNIK, 41 (1), 2020, 49}

Di alam, hidrogen terdapat dalam bentuk senyawa dengan unsur lain, seperti dengan oksigen dalam air atau dengan karbon dalam metana. Sehingga untuk dapat memanfaatkanya, hidrogen harus dipisahkan terlebih dahulu dari senyawanya agar dapat digunakan sebagai bahan bakar. Ada beberapa metode pembuatan gas hidrogen yaitu secara konvensional dan teknologi terbarukan. Secara konvensional dengan memproses bahan bakar fosil yang termasuk didalamnya adalah metode reforming hidrokarbon (steam reforming, oksidasi parsial dan autotermal steam reforming) dan pirolisis. Sedangkan untuk teknologi terbarukan dalam menghasilkan hidrogen memanfaatkan biomassa atau air (Holladay $d k k$., 2009 dan Nikolaidis \& Poullikkas, 2017).

Teknologi sulfur-iodine thermochemical hydrogen cycle merupakan alternative pengembangan produksi hidrogen. Siklus termokimia melibatkan reaksi kimia yang tidak diinginkan dengan satu langkah reaksi dari beberapa reaksi dan proses pemisahan. Siklus termokimia juga mengharuskan setiap langkah reaksi dilakukan dalam kondisi berbeda dan spesifik (Gilis, $d k k$., 2018). Siklus termokimia yang yang telah banyak dipelajari adalah Sulfur-Iodine thermochemical watersplittting cycle. Zhang, dkk., (2014) menyebutkan bahwa saat ini, hal yang diperhatikan untuk memproduksi hidrogen adalah skala pengembangannya, efisiensi, dan biaya rendah. Air yang merupakan salah satu bahan baku yang sering ditemukan di alam, dapat digunakan untuk memproduksi hidrogen melalui reaksi termokimia. Proses sulfur-iodine dipilih sebagai metode produksi hidrogen karena potensial menghasilkan efisiensi panas yang tinggi dari air (Kasahara $d k k$., 2018). Teknologi ini tidak menghasilkan $\mathrm{CO}_{2}$, sehingga mengurangi efek rumah kaca dan isu global warming. Siklus sulfur-iodine memanfaatkan panas dari reaktor nuklir (Leybros $d k k$., 2009).

Reaksi sulfur-iodine dan air pada suhu tinggi dengan memanfaatkan panas dari energi nuklir yang ditunjukkan sebagai berikut:

$2 \mathrm{H}_{2} \mathrm{O}+\mathrm{SO}_{2}+\mathrm{I}_{2} \rightarrow \mathrm{H}_{2} \mathrm{SO}_{4}+2 \mathrm{HI} \mathrm{T}=\sim 120^{\circ} \mathrm{C}$

$$
\begin{array}{lr}
\mathrm{H}_{2} \mathrm{SO}_{4} \rightarrow \mathrm{H}_{2} \mathrm{O}+\mathrm{SO}_{2}+\frac{1}{2} \mathrm{O}_{2} & \mathrm{~T}=\sim 830-900^{\circ} \mathrm{C} \\
2 \mathrm{HI} \rightarrow \mathrm{H}_{2}+\mathrm{I}_{2} & \mathrm{~T}=\sim 400-450^{\circ} \mathrm{C}
\end{array}
$$

Asam sulfat tidak dapat dipisahkan dari hidrogen iodide dengan cara termal tanpa reaksi irreversible. Pemisahan ini dapat dilakukan dengan menambahkan yodium berlebihan (excess), dengan pembentukan dua fase cair $\mathrm{H}_{2} \quad \mathrm{SO}_{4} / \mathrm{H}_{2} \mathrm{O}$ dan fase berat $\mathrm{HI} / \mathrm{I}_{2} / \mathrm{H}_{2} \mathrm{O}$. Siklus sulfur-iodine dapat menghemat biaya dalam memproduksi hidrogen karena dengan memanfaatkan produk dari section satu fase berat ke section yang lain (Brown, et. al., 2003).

Siklus sulfur-iodine dipisahkan menjadi 3 seksi, yaitu reaksi bunsen, pemisahan produk, dan pemurnian HI (Ping, dkk., 2018). Reaksi Bunsen (seksi I) merupakan reaksi $\mathrm{SO}_{2}$ dan $\mathrm{I}_{2}$ yang ditambah air menghasilkan $\mathrm{H}_{2} \mathrm{SO}_{4}$ dan $\mathrm{HI}$. Jumlah air dan iodine berlebihan akan memisahkan $\mathrm{H}_{2} \mathrm{SO}_{4}$ dan $\mathrm{HI}$, serta meningkatkan kosentrasi $\mathrm{H}_{2} \mathrm{SO}_{4}$ dalam air. Seksi II yaitu dekomposisi $\mathrm{H}_{2} \mathrm{SO}_{4}$ untuk recover $\mathrm{SO}_{2}$ dan menghasilkan $\mathrm{O}_{2}$, proses ini memanfaatkan panas dari reaktor nuklir. Seksi III merupakan dekomposisi HI menggunakan reaksi distilasi campuran $\mathrm{HI}, \mathrm{I}_{2}, \mathrm{H}_{2} \mathrm{O}$ untuk recover $\mathrm{I}_{2}$ dan menghasilkan $\mathrm{H}_{2}$, kemudian resirkulasi kembali ke reaksi Bunsen.

Proses produksi hidrogen yang melibatkan perpindahan panas dapat dilakukan proses efisiensi Efisiensi yang dilakukan dapat ditempuh dengan memaksimalkan recovery panas proses ke proses dan meminimalkan kebutuhan energi utilitas. Untuk mencapai tujuan energi recovery maksimum atau energi kebutuhan minimum dibutuhkan sebuah sistem untuk membentuk suatu jaringan penukar panas. Untuk melakukan desain sistem tersebut dapat dilakukan melalui suatu konsep analisis yang disebut dengan analisisi pinch (Wahono, 2005). Salah satu proses produksi hidrogen terbarukan yang memungkinkan untuk dilakukan proses analisis efisiensi energi dengan menggunakan analisis pinch adalah sulfur-iodine thermochemical hydrogen cycle pada seksi III, unit dekomposisi HI (Brown et.al., 2002).

Pada siklus sulfur-iodine seksi III, Dekomposisi HI merupakan bagian penting dalam siklus proses ini karena memproduksi $\mathrm{H}_{2}$, Beberapa unit peralatan dan unit utilitas yang ada dalam sistem proses membutuhkan dan menghasilkan energi yang cukup besar. Sehingga dalam menjalankan proses produksi masih ditemukan beberapa penggunaan sistem energi yang dapat dioptimalkan melalui proses analisis efisiensi energi dengan menggunakan Teknologi Pinch.

Teknologi Pinch adalah teknologi analisis yang dipergunakan untuk menggambarkan termodinamika berdasarkan metode yang menjamin tingkat energi minimum dalam desain dari jaringan penukar panas (Linhoff, 1982). Analisis pinch biasa digunakan untuk menggambarkan aplikasi dari alat dan algoritma dari teknologi Pinch untuk mempelajari proses industri. Banyak program software yang telah dikembangkan dalam anasisis pinch dari proses industri yang komplek dengan cepat dan efisien, seperti Pinch Express ${ }^{\mathrm{TM}}$, Super Target $^{\mathrm{TM}}$, Aspen Pinch ${ }^{\mathrm{TM}}$ dan HINT.

Teknologi Pinch menampilkan sebuah metodologi yang mudah dalam analisis proses kimia secara sistematis dan sistem utilitas di sekitarnya dengan bantuan hukum I dan II termodinamika. Hukum I 


\section{TEKNIK, 41 (1), 2020, 50}

Termodinamika menyebutkan persamaan energi untuk menghitung perubahan entalpi $(\Delta \mathrm{H})$ dalam arus yang mengalir melewati alat penukar panas. Hukum II Termodinamika menentukan arah dari aliran panas. Oleh karena itu, energi panas hanya mengalir dari suhu panas ke dingin. Hal ini menghalangi "aliran temperatur silang" dari aliran panas dan dingin yang melalui alat penukar panas. Dalam alat penukar panas tidak ada aliran panas yang dapat didinginkan dibawah penambahan temperatur arus dingin atau tidak ada arus dingin yang dapat dipanaskan melebihi temperatur dari aliran arus panas. Dalam praktek arus panas hanya dapat didinginkan ke temperatur tertentu yang disebut "temperatur approach" dari mesin penukar panas. Temperatur approach adalah perbedaan temperatur minimum yang diizinkan $(\Delta$ Tmin $)$ dalam penampang aliran temperatur dalam mesin penukar panas. Level temperatur $\Delta$ Tmin saat diamati dalam proses mengacu pada "titik pinch" atau "kondisi pinch". Pinch membatasi kekuatan minimum yang diperbolehkan dalam alat penukar panas dan memaksimalkan proses ke proses penutupan panas dan mengurangi muatan alat eksternal (Sahdev, 2002).

Tujuan dari artikel ini adalah melakukan proses analisis pada sistem produksi $\mathrm{H}_{2}$ dengan siklus sulfuriodine dengan pada seksi III: Dekompisisi HI, menggunakan teknologi pinch sehingga dapat dilakukan efisiensi energi. Analisis pinch variasi terhadap $\Delta T$ min dilakukan untuk mencari recovery energi maksimal, sehingga dapat dijadikan sebagai pertimbangan untuk produksi $\mathrm{H}_{2}$ kaitannya dalam usaha untuk melakukan efisiensi energi sehingga dapat mengurangi biaya utilitas serta mempertimbangkan total cost untuk memproduksi $\mathrm{H}_{2}$. Dengan begitu, aspek tekno-ekonomi dapat tercapai

\section{Bahan dan Metode}

Data arus dan flowsheet yang diperlukan dalam analisa pinch didapatkan pada penelitian sebelumnya (Brown, et. al., 2003). Pada penelitian itu, proses dekomposisi HI pada siklus sulfur iodine merupakan proses terakhir yang menentukan konversi hidrogen. Prosesnya menggunakan reaksi distilasi campuran HI, $\mathrm{I}_{2}, \mathrm{H}_{2} \mathrm{O}$ dengan tujuan merecover $\mathrm{I}_{2}$ dan $\mathrm{H}_{2}$ yang dihasilkan kemudian dialirkan kembali ke reaksi Bunsen seksi (I). Karena pada proses dekomposisi HI single pass, hanya dapat mendekomposisi HI sebanyak $16 \%$, sehingga dilakukan recycle untuk meningkatkan konversi $\mathrm{I}_{2}$ dan $\mathrm{H}_{2}$.

Untuk melakukan analisis pinch pada sistem siklus sulfur-iodine seksi III, langkah-langkahnya meliputi:

1. Diagram alir proses dibuat untuk mengetahui proses pada seksi III
2. Data seperti laju alir massa/mol, kapasitas panas rata-rata $\left(\mathrm{cp}_{\text {mean }}\right)$, suhu masuk (Ts), suhu keluar $(\mathrm{Tt})$, diekstrak dari neraca massa seksi III: dekomposisi HI

3. Tiap-tiap arus/stream dihitung kalornya (Q)

4. Jaringan penukar panas / Heat Exchanger Network (HEN) dibuat untuk menghitung jumlah HE terpasang, biaya, dan luasnya (total cost) menggunakan software HINT

a) Kalor yang dibutuhkan dihitung dengan persamaan

$$
Q=m c p_{\text {mean }} \Delta T
$$

Dimana $\mathrm{M}$ adalah laju alir molar (mol/jam), $\mathrm{cp}_{\text {mean }}$ : adalah kapasitas panas rata-rata aliran $(\mathrm{kW} / \mathrm{mol} \mathrm{K}), \Delta \mathrm{T}$ adalah perbedaan suhu $(\mathrm{K})$

b) Luasan HE dihitung dengan persamaan

$$
A=\frac{Q}{U \Delta T_{L M T D}}
$$

Dimana: A adalah luas HE $\left(\mathrm{m}^{2}\right)$, Q adalah kalor $(\mathrm{kW})$, U adalah koefisien overall penukar panas $\left(\mathrm{kW} / \mathrm{m}^{2} \mathrm{~K}\right)$ dan $\triangle \mathrm{TLMTD}$ adalah log mean temperature difference $(\mathrm{K})$

c) Biaya instalasi HE terpasang dihitung dengan persamaan

$$
\text { Total cost }=a+b A^{2}
$$

Dimana total cost adalah biaya yang dibutuhkan sejumlah HE terpasang; a, b, c adalah konversi, nilainya tergantung dari jenis HE yang digunakan. Pada kasus ini digunakan HE jenis Shell and Tube dimana harga $\mathrm{a}=4600, \mathrm{~b}=920$, dan $\mathrm{c}=0,7$, sedangkan $\mathrm{A}$ adalah luas penampang $\mathrm{HE}\left(\mathrm{m}^{2}\right)$

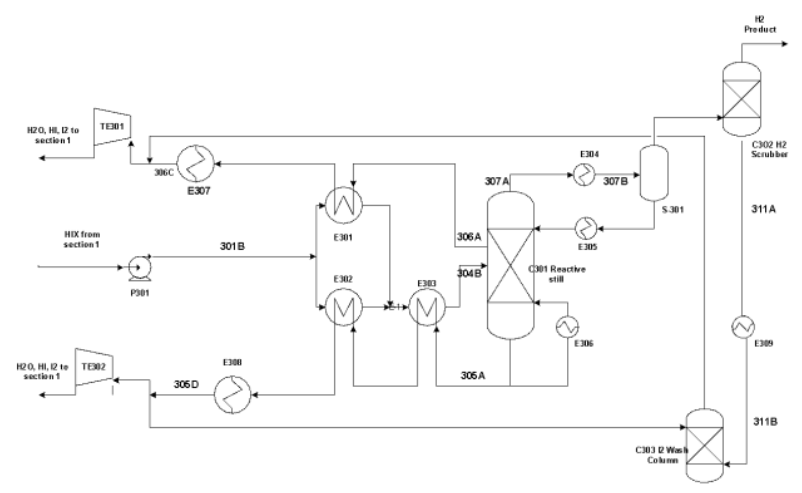

Gambar 1. Diagram Alir seksi III : Dekomposisi HI (Brown, $d k k .$, 2003). 


\section{TEKNIK, 41 (1), 2020, 51}

d) Analisis tekno-ekonomi

Analisis pinch melibatkan pendekatan yang sistematis untuk mengidentifikasi potensi Maximum Energy Recovery dari perpindahan panas secara counter current pada suatu proses. Selain itu, analisis pinch dapat membantu mengidentifikasi jenis kebutuhan utilitas pada detil design Heat Exchanger Network (HEN). Dengan segala tujuan praktis tersebut, analisis pinch dapat dikembangkan untuk HEN dengan tujuan untuk meminimalkan total cost. Dalam paper ini, analisis pinch akan dikaitkan dengan biaya utilitas untuk memproduksi $\mathrm{H}_{2}$ dalam skala pilot.

\section{Hasil dan Pembahasan}

Dari diagram alir dan neraca massa pada seksi III: dekomposisi HI, dilakukan ekstrak data yang nantinya digunakan untuk menghitung kalor di tiap-tiap streamnya (Q). Data-data yang dibutuhkan untuk analisis pinch, seperti laju alir mol tiap-tiap stream, kapasitas panas rata-rata (cpmean), temperature supply (Ts) dan temperature target (Tt), diekstrak dari neraca massa sesuai dengan diagram alir seksi III. Data yang telah diekstrak ditunjukkan pada Tabel 1.

Kurva komposit pada Gambar 2 menunjukkan plotting suhu versus heat load $(\mathrm{H})$. Dengan $\Delta$ Tmin sebesar $10 \mathrm{~K}$, titik pinch atas berada pada $403,15 \mathrm{~K}$ dan titik pinch bawah 393,15 K. Penghematan energi (Maximum energy recovery) yang dapat dicapai adalah sebesar 1557,12 kW. Sementara beban pemanasan dan pendinginan secara berurutan adalah sebesar $21,32 \mathrm{~kW}$ dan $253,10 \mathrm{~kW}$. Jaringan alat penukar kalor dengan $\Delta$ tmin $10 \mathrm{~K}$ disusun sebagaimana Gambar 3.

Evaluasi energi pada sistem tersebut tidak merupakan threshold, artinya sistem memiliki titik

Tabel 1. Ekstrak Data Seksi III

\begin{tabular}{|c|c|c|c|c|c|c|c|c|}
\hline Stream & $\begin{array}{c}\text { Jenis } \\
\text { aliran }\end{array}$ & $\begin{array}{c}\text { Ts } \\
(K)\end{array}$ & $\begin{array}{c}\mathbf{T t} \\
(\mathbf{K})\end{array}$ & $\begin{array}{l}\Delta \mathbf{T} \\
(\mathbf{K})\end{array}$ & $\begin{array}{c}\mathbf{m} \\
(\mathbf{m o l} \\
/ \text { jam })\end{array}$ & $\begin{array}{c}\mathbf{c p} \\
\text { mean } \\
(\mathrm{W} / \\
\text { mol K) }\end{array}$ & $\begin{array}{c}\text { m.cp } \\
(\mathbf{k W} \\
\text { /K) }\end{array}$ & $\begin{array}{c}\text { Heat } \\
\text { load } \\
(\mathrm{kW})\end{array}$ \\
\hline $\begin{array}{l}306 \mathrm{~A}- \\
306 \mathrm{C}\end{array}$ & Hot & 524,15 & 368,15 & 156 & 76,63 & 84,32 & 6,46 & 1007,76 \\
\hline $\begin{array}{l}305 \mathrm{~A}- \\
305 \mathrm{D}\end{array}$ & Hot & 583,15 & 393,15 & 190 & 48,51 & 84,77 & 4,11 & 780,9 \\
\hline $\begin{array}{l}307 \mathrm{~A}- \\
307 \mathrm{~B}\end{array}$ & Hot & 494,15 & 298,15 & 196 & 3,33 & 31,95 & 0,11 & 21,56 \\
\hline $\begin{array}{l}301 \mathrm{~B}- \\
304 \mathrm{~B}\end{array}$ & Cold & 393,15 & 535,15 & 142 & 126,16 & 85,58 & 10,80 & 1553.6 \\
\hline $\begin{array}{l}308 \mathrm{~A}- \\
308 \mathrm{~B}\end{array}$ & Cold & 298,15 & 494,15 & 196 & 2,31 & 80,98 & 0,19 & 37,24 \\
\hline $\begin{array}{l}311 \mathrm{~A}- \\
311 \mathrm{~B}\end{array}$ & Cold & 298,15 & 393,15 & 95 & 1,05 & 75,37 & 0,08 & 7,6 \\
\hline
\end{tabular}

pinch atas dan bawah dan masih membutuhkan beban pemanasan dan pendinginan. Recovery energy terjadi pada bagian ketika aliran panas sebelum masuk reaktor 305 A / 305 D, panas ini dimanfaatkan oleh aliran dingin keluar reaktor yaitu 301B / 304B. Beban pendinginan sebesar $208,05 \mathrm{~kW}$ dan $33,4965 \mathrm{~kW}$, secara berturutturut digunakan untuk aliran panas (306 A / $306 \mathrm{C}$ dan 305 A / 305 D) yang keluar reaktor untuk mencapai masing-masing suhu target nya, dan digunakan di kondenser sebanyak $11,55 \mathrm{~kW}$ pada proses distilasi. Sedangkan beban pemanasan sebanyak $21,32 \mathrm{~kW}$ digunakan untuk memanasi aliran dingin sebelum masuk reaktor hingga suhu $535 \mathrm{~K}$. Tabel 2 dibawah ini merupakan ringkasan evaluasi energi pada seksi III dengan $\Delta \mathrm{T} \min 10 \mathrm{~K}$

Dapat disimpulkan, bahwa dengan $\Delta$ Tmin sebesar $10 \mathrm{~K}$, menghasilkan penghematan energi sebesar $1557,12 \mathrm{~kW}$ dengan biaya sebesar \$60170,59. Selanjutnya, dicoba untuk mengetahui dampak penghematan energi, beban utilitas, dan total cost jika $\Delta$ Tmin divariasikan sebesar $15 \mathrm{~K}$ dan $20 \mathrm{~K}$.

Pada Gmbar 4, kurva komposit dengan $\Delta \mathrm{T}$ minimal sebesar $15 \mathrm{~K}$, titik pinch atas barada di 408,15 $\mathrm{K}$ dan titik pinch bawah 393,15 K. Maksimum energy recovery yang dapat dicapai adalah sebesar $1503,72 \mathrm{~kW}$. Sedangkan beban pemanasan dan pendinginan secara berurutan adalah sebesar 74,72 kW dan 306,50 kW.

Ternyata, setelah menggeser delta $\mathrm{T}$ sebesar 15 $\mathrm{K}$, dengan jumlah HE yang sama, beban pemanasan (heater) di atas pinch dan beban pendinginan (cooler) dibawah area titik pinch, semakin banyak, itu artinya, maximum energy recovery semakin kecil, sehingga luasan HE yang diperlukan juga makin kecil.

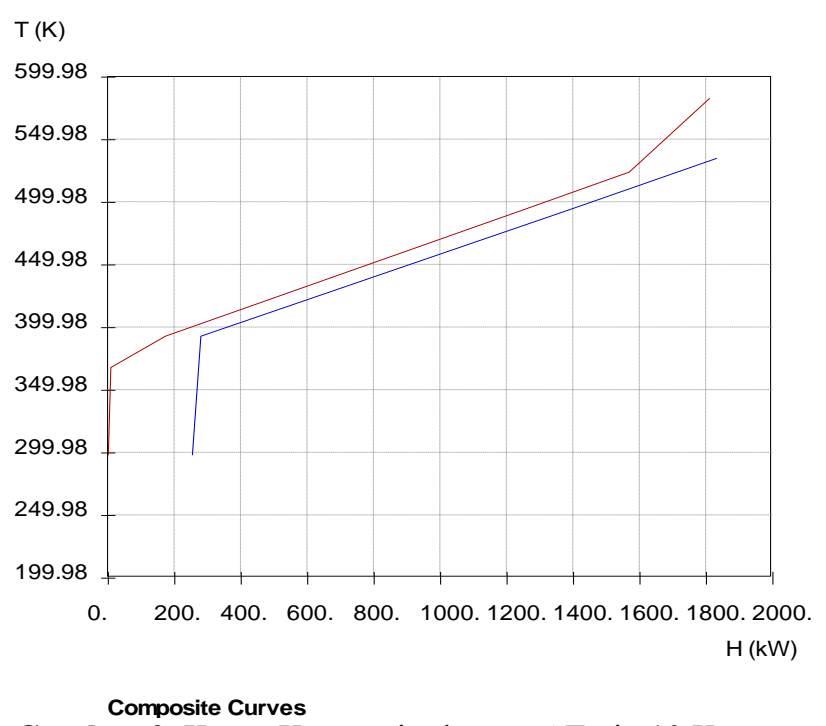

Gambar 2. Kurva Komposit dengan $\Delta \mathrm{Tmin} 10 \mathrm{~K}$ 


\section{TEKNIK, 41 (1), 2020, 52}

Tabel 2. Evaluasi Seksi III Setelah Analisis Pinch dengan $\Delta \mathrm{Tmin} 10 \mathrm{~K}$.

\begin{tabular}{|c|c|c|}
\hline \multicolumn{2}{|c|}{ Analisis Parameter } & Jumlah \\
\hline \multirow{2}{*}{$\begin{array}{l}\text { Sebelum analisis } \\
\text { pinch }\end{array}$} & Q panas $(\mathrm{kW})$ & $1.578,44$ \\
\hline & $\mathrm{Q}$ dingin $(\mathrm{kW})$ & $1.810,22$ \\
\hline \multirow{2}{*}{$\begin{array}{l}\text { Sesudah analisis } \\
\text { pinch }\end{array}$} & $\begin{array}{l}\text { Beban pemanasan } \\
(\mathrm{kW})\end{array}$ & 21,32 \\
\hline & $\begin{array}{l}\text { Beban pendinginan } \\
(\mathrm{kW})\end{array}$ & 253,10 \\
\hline \multicolumn{2}{|c|}{ Maximum energy recovery (MER) (kW) } & $1.557,12$ \\
\hline \multirow{2}{*}{\multicolumn{2}{|c|}{$\begin{array}{l}\text { Jumlah HE terpasang } \\
\text { Total cost HE ternasang (\$) }\end{array}$}} & 10 \\
\hline & & $60.170,59$ \\
\hline
\end{tabular}

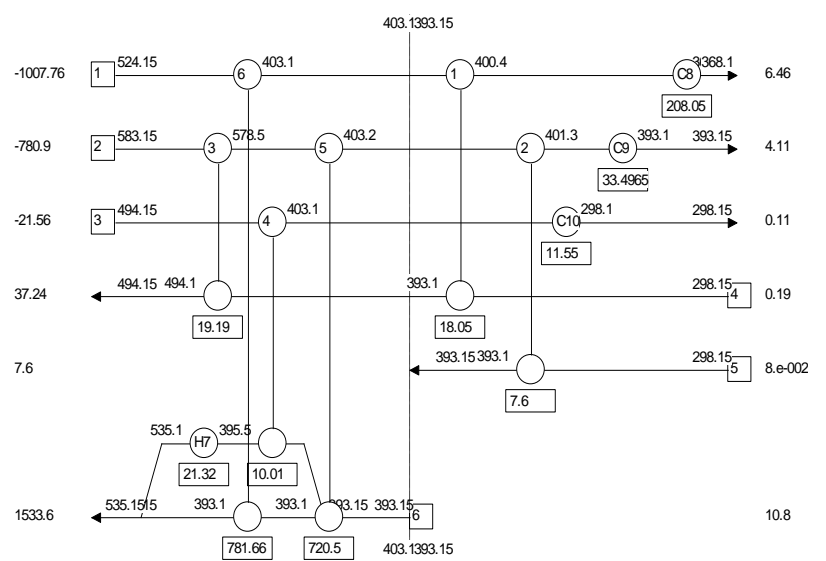

Gambar 3. Jaringan alat Penukar Kalor $\Delta$ Tmin $10 \mathrm{~K}$

Pada Gambar 6, kurva komposit dengan $\Delta$ Tmin sebesar $20 \mathrm{~K}$, menghasilkan titik pinch atas barada di 413,15 $\mathrm{K}$ dan titik pinch bawah 393,15 K. Maksimum energy recovery yang dapat dicapai adalah sebesar $1450,32 \mathrm{~kW}$. Sedangkan beban pemanasan dan pendinginan secara berurutan adalah sebesar 128,12 kW dan 359,90 kW.

Hasil yang sama juga menunjukkan bahwa ketika $\Delta$ Tmin digeser lagi sejauh $20 \mathrm{~K}$, dengan jumlah $\mathrm{HE}$ yang sama, beban pemanasan (heater) di atas pinch dan beban pendinginan (cooler) dibawah area titik pinch, semakin banyak, itu artinya, semakin besar biaya utilitasnya, selain itu maximum energy recovery semakin kecil, sehingga luasan HE yang diperlukan juga makin kecil. Berikut merupakan kesimpulan yang didapatkan setelah melakukan analisis pinch dengan berbagai $\Delta$ Tmin.

Berdasarkan Tabel 3, dengan jumlah HE yang sama, dengan $\Delta$ Tmin $10 \mathrm{~K}$, menghasilkan MER yang paling besar, yaitu sebesar 1557,12 kW. Sedangkan apabila dikaitkan dengan seberapa banyak energi untuk memproduksi hidrogen, Brown $d k k$., 2003, menyebutkan per $\mathrm{kW}$ nya, dapat dihasilkan hidrogen sebesar 12,9 kg. Selain itu, harga

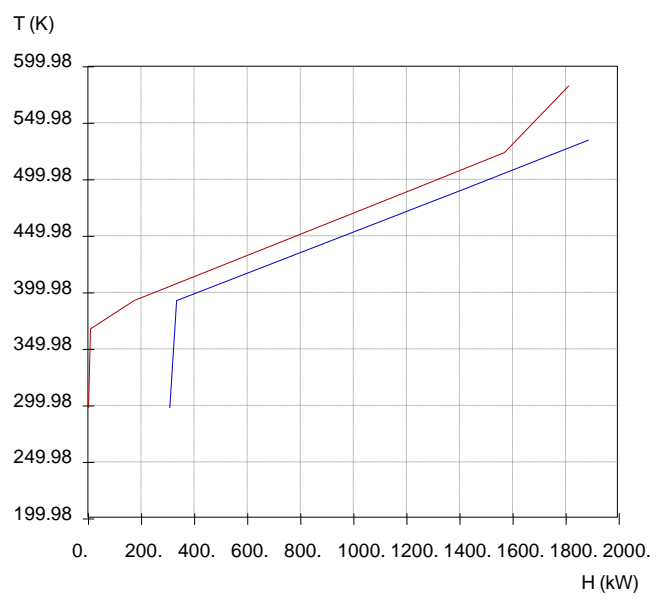

Gambar 4. Kurva Komposit dengan $\Delta \mathrm{Tmin} 15 \mathrm{~K}$

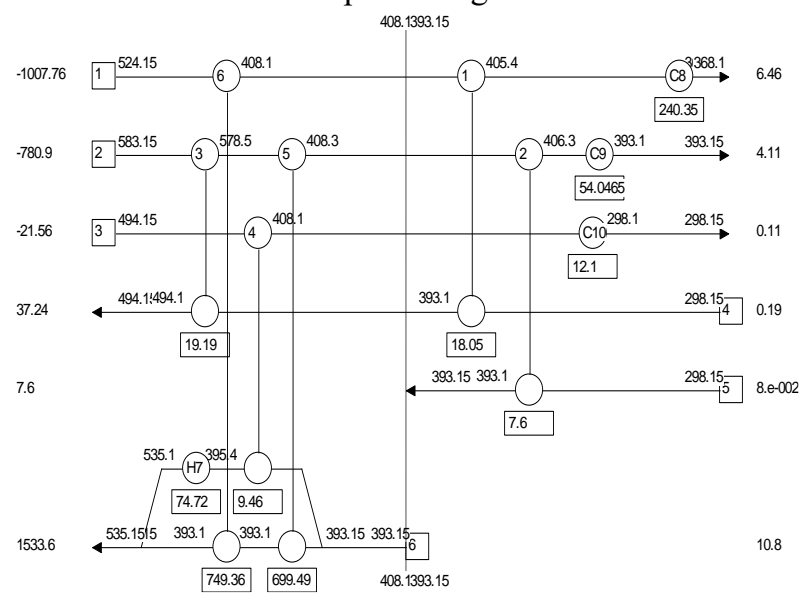

Gambar 5. Matching Aliran dengan $\Delta \mathrm{Tmin} 15 \mathrm{~K}$

$\mathrm{H}_{2}$ per kg adalah $\$ 1,42$. Pada existing process, energi yang dibutuhkan untuk memproduksi $\mathrm{H}_{2}$ adalah $3388,66 \mathrm{~kW}$ (Brown, 2003). Setelah analisis pinch, energi yang dibutuhkan pada $\Delta \operatorname{Tmin} 10 \mathrm{~K}, 15 \mathrm{~K}$ dan $20 \mathrm{~K}$ dapat menghasilkan hidrogen sebanyak $23626,87 \mathrm{~kg}, 24315,73 \mathrm{~kg}$, dan $25004,58 \mathrm{~kg}$ secara berturut-turut. Semakin banyak $\mathrm{H}_{2}$ yang dihasilkan, maka total cost produksi $\mathrm{H}_{2}$ nya juga meningkat, sehingga dengan $\Delta$ Tmin $20 \mathrm{~K}$, membutuhkan total cost produksi hidrogen paling banyak. Dengan fakta tersebut, dipilih $\Delta$ Tmin sebesar $10 \mathrm{~K}$. Alasanya karena dengan jumlah HE yang sama, energy recovery nya paling besar. Akibatnya beban dan biaya utilitas yang dibutuhkan paling rendah. Selain itu, ditinjau dari total cost produksi $\mathrm{H}_{2}$, dengan $\Delta \mathrm{Tmin} 10 \mathrm{~K}$, membutuhkan biaya paling rendah. Hal ini sesuai dengan Rossiter (2010) yang menyatakan bahwa perubahan proses untuk mengefisiensikan energi dapat ditentukan berdasarkan pemilihan $\Delta$ Tmin yang dapat berpengaruh pada trade-off antara total cost dan biaya energi. Semakin kecil $\Delta$ Tmin, HEN yang dihasilkan akan menurunkan biaya energi. 


\section{TEKNIK, 41 (1), 2020, 53}

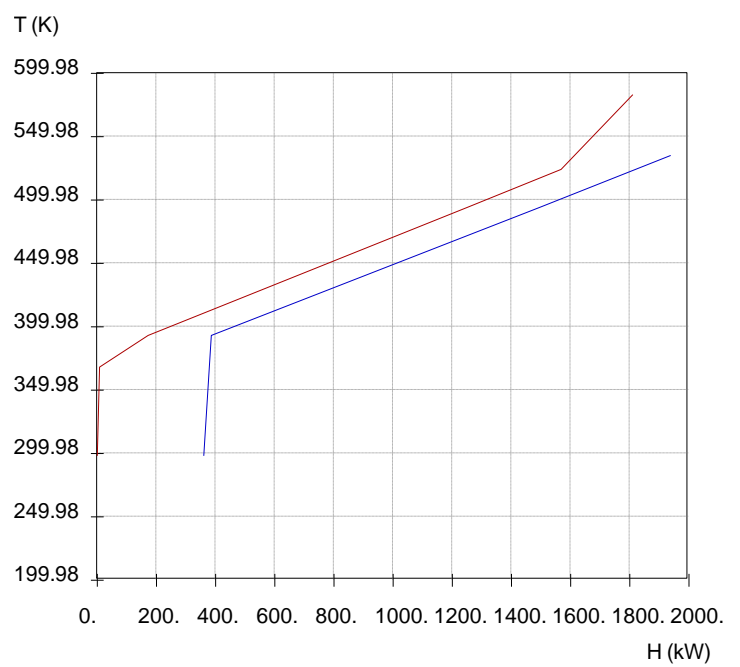

Gambar 6. Kurva Komposit dengan $\Delta \mathrm{T}_{\min } 20 \mathrm{~K}$

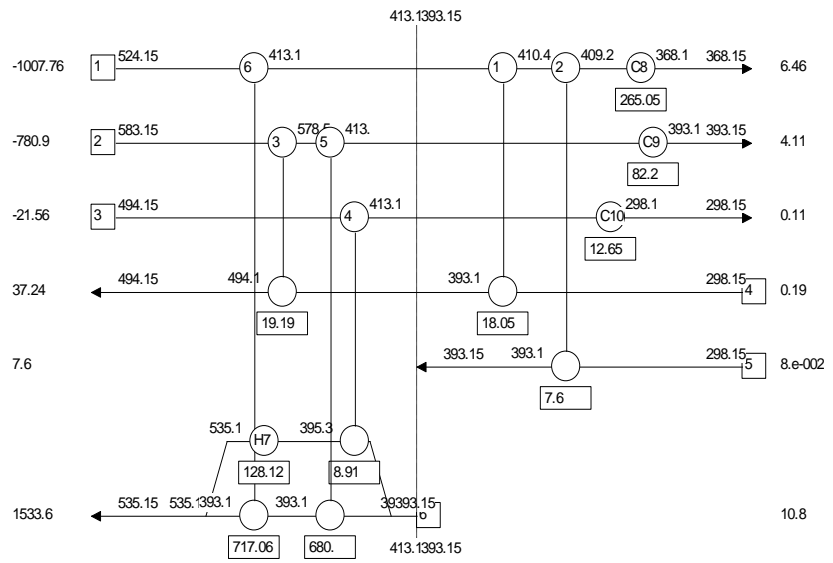

Gambar 7. Matching Aliran dengan $\Delta \operatorname{Tmin} 20 \mathrm{~K}$

Tabel 3. Ringkasan Evaluasi Seksi III Produksi Hidrogen Menggunakan Analisis Pinch dengan Berbagai Minimum Temperature Approach ( $\triangle T$ Tin)

\begin{tabular}{llll}
\hline \multicolumn{1}{c}{ Parameter } & \multicolumn{1}{c}{$\begin{array}{c}\Delta \mathbf{T}_{\mathbf{m i n}}=\mathbf{1 0} \\
\mathbf{K}\end{array}$} & \multicolumn{1}{c}{$\begin{array}{c}\boldsymbol{\Delta} \mathbf{T}_{\mathbf{m i n}}=\mathbf{1 5} \\
\mathbf{K}\end{array}$} & $\begin{array}{c}\Delta \mathbf{T}_{\mathbf{m i n}}=\mathbf{2 0} \\
\mathbf{K}\end{array}$ \\
\hline $\begin{array}{l}\text { Jumlah HE terpasang } \\
\text { Total cost HE }\end{array}$ & 10 & 10 & 10 \\
terpasang (\$) & 60170,59 & 59026,93 & 58255,22 \\
$\begin{array}{l}\left.\text { Luas HE (m }{ }^{2}\right) \\
\text { Beban pemanasan } \\
(\mathrm{kW})\end{array}$ & 30,35 & 26,13 & 23,30 \\
$\begin{array}{l}\text { Beban pendinginan } \\
\text { (kW) }\end{array}$ & 21,32 & 74,72 & 128,12 \\
$\begin{array}{l}\text { Maximum energy } \\
\text { recovery }(\text { MER) }(\mathrm{kW})\end{array}$ & 1557,12 & 1503,72 & 1450,32 \\
$\begin{array}{l}\text { Energi sebelum } \\
\text { analisis pinch }(\mathrm{kW})\end{array}$ & & 3388,66 & \\
$\begin{array}{l}\text { Energi pada } \Delta \mathrm{T}_{\text {min }} \\
\text { (kW) }\end{array}$ & 1831,54 & 1884,94 & 1938,34 \\
$\begin{array}{l}\text { Hidrogen yang } \\
\text { dihasilkan }(\mathrm{kg})\end{array}$ & 23626,87 & 24315,73 & 25004,58 \\
$\begin{array}{l}\text { Total cost produksi } \\
\mathbf{H}_{\mathbf{2}} \text { (\$) }\end{array}$ & $\mathbf{3 3 5 5 0 , 1 5}$ & $\mathbf{3 4 5 2 8 , 3 4}$ & $\mathbf{3 5 5 0 6 , 5 0}$ \\
\hline
\end{tabular}

\section{Kesimpulan}

Seksi III yang merupakan proses dekomposisi HI pada proses produksi hidrogen, merupakan proses yang krusial. Oleh karena itu, dibutuhkan evaluasi dalam berbagai segi, terutama efisiensi energi. Variasi minimum temperature approach $(\Delta \mathrm{Tmin})$ digunakan untuk menghitung seberapa besar sistem merecover panas. Hasil analisa pinch menunjukkan pada $\Delta T \min 10$ $\mathrm{K}$ dihasilkan MER paling tinggi. Ini menyebabkan beban utilitas berkurang yang pada akhirnya menurunkan biaya. Sedangkan luasan HE terpasang dengan jumlah 10 adalah sebesar $30,35 \mathrm{~m}^{2}$ dengan total cost sebesar \$60170,59. Besarnya luasan HE linier dengan biaya operasional nya (total cost). Selain itu, total cost untuk produksi $\mathrm{H}_{2}$ paling rendah juga diperoleh pada $\Delta$ Tmin $10 \mathrm{~K}$. Dari analisis tersebut, dapat disimpulkan bahwa untuk memperoleh pemanfaatan panas besar dan total cost produksi $\mathrm{H}_{2}$ yang rendah, maka $\Delta$ Tmin $10 \mathrm{~K}$ merupakan rekomendasi temperature approach.

\section{Daftar Pustaka}

Brown, L. C., Besenbruch, G.E., Lentsch, R.D., Schultz, K.R., Funk, J.F., Pickard, P.S., Marshall, A.C., Showalter, S.K., (2003) High Efficiency Generation of Hydrogen Fuels Using Nuclear Power; GA-A24285; General Atomics: San Diego, CA, USA

Brown, L.C., Lentsch, R.D., Besenbruch, G.E., Schultz, K.R., Funk, J.E., (2003). Alternatif Flowsheet for the Sulfur-Iodine Thermochemical Hydrogen Cycle. General Atomic Project 30171, U.S Department of Energy ang Grant, Proceedings of AIChE.

Gilis, R. J., Al-Ali, k., Green, W.H., (2018). Thermochemical Production of Hydrogen from Hydrogen Sulphide with Iodine Thermochemical Cycles, Journal of Hydrogen Energy, 43, 1293912947.Y

Holladay, J. D., Hu, J., King D.L., Wang, Y., (2009). An Overview of Hydrogen Production Technologies. Catalysis Today, 139(4), 244-260.

Kasahara, S., Imai, Y., Suzuki, K., Iwatsuki, J., Terada, A., and Yan, X.L., (2018). Conceptual Design of The Iodine-Sulfur Process Flowsheet with More Than 50\% Thermal Efficiency for Hydrogen Production, Nuclear Engineering and Design, 329, 213-222 .

Linhoff, B. (1982). A User Guide on Process Integration for Efficient Use of Energy, The Institution of Chemical Engineers, England.

Leybros, J., Carles, P., and Borgard, J.M. (2009). Countercurrent Reactor Design and Flowsheet for 


\section{TEKNIK, 41 (1), 2020, 54}

Iodine-Sulphur Thermochemical Water Splitting Process. International Journal of Hydrogen Energy, 34, 9060-9075.

Nikolaidis, P., \& Poullikkas, A. (2017). A Comparative Overview of Hydrogen Production Processes. Renewable and Sustainable Energy Reviews, 67, 597-611.

Ping, Z., Laijun, W., Songzhe, C., and Jingming, X., (2018). Progress of Nuclear Hydrogen Production through The Iodine-Sulfur Process in China, Renewable and Suitable Energy Review, 81, 1802-1812.

Rossister, A. P., (2010). Improve Energy Efficiency via Heat Integration. American Institute of Chemical Engineering
Sahdev dan Mukesh. (2002). Pinch Technology: Basics for Beginners, diakses pada 10 Juli 2019, dapat diakses pada http://www.cheresources.com

Wahono, S.K. (2005). Analisa Efisiensi Energi Menggunakan Teknologi Pinch pada Sistem Proses Unit Phonska PT. Perokimia Gresik Sebagai Alternatif Penghematan Energi, Seminar Nasional Fundamental dan Aplikasi Teknik Kimia, ISSN: 1410-566.

Zhang, Y., Ying, Z., Zhou, J., Liu, J., Wang, and Cen K., (2014). Electrolysis of the Bunsen Reaction and Properties of the Membrane in the SulfurIodine Thermochemical Cycle, Industrial \& Engineering Chemisty Research, 53, 1358113588 